\title{
Similarities between bovine and human germline development revealed by single-cell RNA sequencing
}

\author{
Delia Alba Soto and Pablo Juan Ross( \\ Department of Animal Science, University of California, Davis, California, USA \\ Correspondence should be addressed to P J Ross; Email: pross@ucdavis.edu
}

\begin{abstract}
The germ cell lineage ensures the creation of new individuals and perpetuates the genetic information across generations. Primordial germ cells are pioneers of gametes and exist transiently during development until they differentiate into oogonia in females, or spermatogonia in males. Little is known about the molecular characteristics of primordial germ cells in cattle. By performing single-cell RNA-sequencing, quantitative real-time PCR, and immunofluorescence analyses of fetal gonads between 40 and 90 days of fetal age, we evaluated the molecular signatures of bovine germ cells at the initial stages of gonadal development. Our results indicate that at 50 days of fetal age, bovine primordial germ cells were in the early stages of development, expressing genes of early primordial germ cells, including transcriptional regulators of human germline specification (e.g. SOX17, TFAP2C, and PRDM1).

Bovine and human primordial germ cells also share expression of KIT, EPCAM, ITGA6, and PDPN genes coding for membrane-bound proteins, and an asynchronous pattern of differentiation. Additionally, the expression of members of Notch, Nodal/Activin, and BMP signaling cascades in the bovine fetal ovary, suggests that these pathways are involved in the interaction between germ cells and their niche. Results of this study provide insights into the mechanisms involved in the development of bovine primordial germ cells and put in evidence similarities between the bovine and human germline.
\end{abstract}

Reproduction (2021) 161 239-253

\section{Introduction}

The specification of primordial germ cells (PGCs), the progenitors of sperm and eggs, occurs around the onset of gastrulation by the inductive signaling of bone morphogenetic proteins (BMP) on a group of cells that are initially destined toward a somatic mesodermal fate (Lawson et al. 1999, Saitou et al. 2002, Kobayashi et al. 2017, Chen et al. 2019). Even though the signaling pathways that operate during PGC specification are conserved across mammals (Nikolic et al. 2016), the origin of the signaling molecules, the key transcriptional regulators, and their hierarchy are divergent between species (Kojima et al. 2017).

In mice, the period of PGC development lasts around 7 days. This process is initiated by BMP4 signaling on WNT-primed cells, which activates PRDM1 (also known as BLIMP1) and PRDM14. Together with TFAP2C, a direct target of PRDM1, these genes act in combination to induce PGC fate (Ohinata et al. 2005, Yamaji et al. 2008). The PRDM1-PRDM14-TFAP2C tripartite genetic network acts to repress the somatic mesodermal program, induce re-expression of pluripotency genes, initiate expression of PGC genes, and prompt genome-wide epigenetic reprogramming (Saitou et al. 2002, Yabuta et al. 2006, Seki et al. 2007); all key events involved in the specification of PGCs. After specification, PGCs follow guidance cues that will ultimately lead them to the genital anlage. Upon colonization of the undifferentiated developing gonad, PGCs undergo synchronous mitotic divisions with incomplete cytokinesis, forming nests of interconnected germ cells (Pepling \& Spradling 1998). The PGC development period ends when female PGCs enter meiotic prophase or male PGCs enter mitotic quiescence (McLaren \& Southee 1997). In the ovary, meiosis initiation is triggered by retinoic acid signaling which in the testis is antagonized by the cytochrome P450 activity of Sertoli cells (Bowles et al. 2006, Koubova et al. 2006).

In humans, the period of PGC development lasts around 7 weeks (from week 2 to week 9 of fetal development) (Tang et al. 2015). Activation of BMP signaling leads to upregulation of PRDM1, which in primates and pigs, is triggered by SOX17, a key regulator of PGC specification (Irie et al. 2015, Kobayashi et al. 2017, Kojima et al. 2017). BMP signaling initially upregulates TFAP2C independently from SOX17, which in combination with PRDM1 establish the gene expression program of human PGCs (Kojima et al. 2017). Upon specification, human PGCs migrate and colonize the genital ridge to extensively proliferate until they enter meiosis asynchronously in females (Anderson et al. 2007) or enter mitotic quiescence and undergo meiosis after puberty in males (Tang et al. 2015). 
Despite the advances in mice and humans, PGC specification and development in livestock species are largely unknown. Similar to humans, the period of bovine PGC development lasts around 6 weeks (from week 2 to week 8 of fetal development) (Lavoir et al. 1994, Wrobel \& Süß 1998). At 40 days of fetal development, the undifferentiated bovine gonad undergoes sexual differentiation, and then female germ cells initiate meiosis between 70 and 80 days of fetal age (Erickson 1966). At the molecular level, bovine PGCs are characterized by nonspecific alkaline phosphatase (AP) activity (Wrobel \& Süß 1998), expression of well-conserved germline markers such as the tyrosine-kinase receptor KIT (also known as CKIT) (Kritzenberger \& Wrobel 2004), and the RNA-binding proteins NANOS3 (Ideta et al. 2016), DDX4 (also known as VASA) (Pennetier et al. 2004, Bartholomew \& Parks 2007, Luo et al. 2013) and DAZL (Hummitzsch et al. 2013). However, the molecular signatures that characterize the bovine germline during early gonadal development have not been elucidated, due in part to the challenges associated with studying PGCs. During their initial development, PGCs are embedded in the developing embryo in small numbers (Barton et al. 2016, Cantú \& Laird 2017) and even though human and mice PGCs can be purified by cell sorting, antibodies to successfully target and isolate bovine PGCs are not commercially available. To overcome this limitation and elucidate the molecular signatures that characterize the bovine germline during early gonadal development, we performed single-cell RNAsequencing (scRNA-seq), quantitative real-time PCR (RT-qPCR), and immunofluorescence analyses of fetal gonads between 40 and 90 days of age. At day 50 bovine PGCs were in early stages of development and shared with the human germline expression of transcriptional regulators and surface markers, and an asynchronous progression of differentiation.. Bovine PGCs and their somatic counterparts expressed members of the BMP, Activin/Nodal, and Notch signaling cascades, suggesting that these pathways may have roles in coordinating the events of gonad development in cattle.

\section{Materials and methods}

\section{Tissue collection and processing}

Bovine fetuses were obtained from a local abattoir and transported on ice to the laboratory within $3 \mathrm{~h}$ of retrieval. Fetuses were inspected for normal development and the crown-rump length (CRL) was measured to estimate gestational age (DesCôteaux et al. 2009). Gonads were identified based on their location within the abdominal cavity, anatomy, and relationship with neighboring organs (mesonephros and/or kidneys). Tissues retrieved for histology were fixed in $4 \%$ paraformaldehyde for $24 \mathrm{~h}$ at $4{ }^{\circ} \mathrm{C}$ and stepwise dehydrated through an ethanol gradient and processed in a VIP Tissue Tech processor (Sakura Finetek). Tissue was then embedded in paraffin, sectioned at $5 \mu \mathrm{m}$ thickness and stained with hematoxylin and eosin (H\&E). Gonads collected for immunostaining analyses were fixed in $4 \%$ paraformaldehyde for $5 \mathrm{~h}$ at $4^{\circ} \mathrm{C}$, washed and transferred to $30 \%$ sucrose until embedding in Tissue-Tek optimal cutting temperature (OCT) compound (4883, Sakura Finetek). Cryoblocks were sectioned at $10 \mu \mathrm{m}$ thickness and tissue sections were stored at $-20^{\circ} \mathrm{C}$ until staining. Gonads retrieved for scRNA-seq were washed in ice-cold PBS and slow frozen in DMEM containing 20\% FBS and $10 \%$ DMSO using a freezing device (5100-0001, Thermo Scientific). Fetal ovaries and testes harvested for quantitative RT-PCR were snap-frozen in liquid nitrogen and stored at $-80^{\circ} \mathrm{C}$ until RNA was extracted. Samples utilized in this study are listed in Table 1.

\section{Immunofluorescence analysis}

Cryosections were washed to remove the OCT compound before unmasking for $10 \mathrm{~min}$ in a steamer in $10 \mathrm{mM}$ sodium citrate buffer, $\mathrm{pH}$ 6.0. Blocking was performed by incubating the tissue sections with $0.3 \mathrm{mM}$ glycine and $10 \%$ normal donkey serum for $1 \mathrm{~h}$, at room temperature. Tissue sections were then incubated overnight at $4^{\circ} \mathrm{C}$ with the following primary antibodies: anti-PRDM1 (1:50; 14-5963-80, Invitrogen), antiOCT4 (1:500; sc-8628, Santa Cruz Biotechnology), anti-DAZL (1:500; Ab34139, Abcam), anti-DDX4 (1:500; Ab13840, Abcam). Secondary antibody incubation was performed for $1 \mathrm{~h}$ at room temperature and Hoechst 33342 was used for counterstaining. Tissue sections were mounted using ProLong Gold Antifade (P36934, Invitrogen) and images captured using

Table 1 List of bovine fetuses harvested for this study.

\begin{tabular}{|c|c|c|c|}
\hline CRL (cm) & Sex & $\begin{array}{l}\text { Estimated fetal } \\
\text { age (days) }\end{array}$ & Analysis \\
\hline 2 & N/A & 40 & $H \& E$ \\
\hline 2 & Male & 40 & IMF \\
\hline 2.5 & Male & 45 & IMF \\
\hline 3 & Female & $45-50$ & IMF \\
\hline 3 & Male & $45-50$ & RT-qPCR \\
\hline 3.5 & Female & 50 & $\mathrm{AP}$ \\
\hline 3.5 & Female & 50 & RT-qPCR \\
\hline 4 & Female & 50 & scRNA-seq \\
\hline 4 & Female & 50 & scRNA-seq \\
\hline 4.5 & Female & 50 & $\mathrm{H} \& \mathrm{E}$ \\
\hline 4.5 & Female & 50 & RT-qPCR \\
\hline 5.5 & Female & $50-60$ & RT-qPCR \\
\hline 5.5 & Male & $50-60$ & RT-qPCR \\
\hline 6 & Female & 60 & IMF \\
\hline 6.3 & Male & 60 & IMF \& AP \\
\hline 8 & Male & $60-70$ & RT-qPCR \\
\hline 8.3 & Female & $60-70$ & RT-qPCR \\
\hline 11 & Female & 80 & RT-qPCR \\
\hline 11 & Male & 80 & RT-qPCR \\
\hline 12 & Male & 80 & IMF \& AP \\
\hline 14 & Female & 90 & RT-qPCR \\
\hline 14 & Male & 90 & RT-qPCR \\
\hline 15.5 & Female & 90 & IMF \\
\hline 16 & Female & 90 & IMF \\
\hline
\end{tabular}

$\mathrm{AP}$, detection of alkaline phosphatase activity; CRL, crown-rump length; H\&E, hematoxylin and eosin staining; IMF, immunofluorescence staining; N/A, not available; RT-qPCR, quantitative real-time PCR; sCRNA-seq: single-cell RNA-sequencing. 
a Leica TCS SP8STED 3X laser-scanning confocal microscope. Image processing was performed using Image) (v2.0.0-rc69/1.52n). Immunostaining of mesonephros was utilized as negative control when germline-specific proteins were detected.

\section{Alkaline phosphatase staining}

Detection of AP activity was performed using the Alkaline Phosphatase Staining Kit II (00-0055; Stem-gent) adapting the manufacturer's protocol for tissue sections. Briefly, cryosections were washed in PBS supplemented with $0.05 \%$ Tween 20 and incubated with freshly prepared AP Substrate Solution (provided with the kit) in the dark at room temperature for $15 \mathrm{~min}$. The reaction was stopped by washing tissue sections in PBS and stained sections were mounted in ClearMount mounting medium (MMC0112, American MasterTech). Imaging was performed using a Q Imaging camera on an Olympus $\mathrm{BH} 2$ microscope.

\section{Sex determination by polymerase chain reaction}

Fetuses less than 50 days of fetal age ( $4 \mathrm{~cm} C R L$ ) were sexed by PCR targeting the DEAD box helicase 3 gene (DDX3X/DDX3Y), which allows discrimination between $X$ and $Y$ chromosomes based on amplicon size (Gokulakrishnan et al. 2012). DNA extraction was performed using the DNeasy Blood and Tissue Kit (69504, Qiagen) according to manufacturer's protocol. DNA was quantified using a NanoDrop 2000C Spectrophotometer (Thermo Scientific) and amplified using the Go Taq Hot Start Green Master Mix. Amplicons were observed by agarose gel electrophoresis stained with ethidium bromide. Genomic DNA from adult testes and ovaries were used as controls.

\section{CDNA preparation and quantitative $R T$-PCR}

Total RNA was extracted using the RNeasy Mini Kit (74104, Qiagen) and DNase treated with the RNase-Free DNase Set (79254, Qiagen). After extraction, RNA was quantified using the Qubit RNA BR Assay Kit (Q10211, Invitrogen) and reverse transcribed using SuperScript III Reverse Transcriptase (18080044, Invitrogen) according to the manufacturer's protocols.

Evaluation of gene expression was performed using PowerUp SYBR Green Master Mix (A25742, Applied Biosystems) on a QuantStudio 3 Real-Time PCR System (A28137, Applied Biosystems). The Primer Quest tool (Integrated DNA Technologies) was used to design primers (Table 2) spanning an exon-exon junction. Samples were run in technical duplicates and relative expression was calculated by the delta Ct method, normalizing values to the HMBS housekeeping gene. cDNA from adult testes and ovaries were used as controls.

\section{Fetal gonad dissociation for single cell RNA- sequencing}

Slow-frozen gonads from two independent replicates of approximately 50 days of fetal age $(4 \mathrm{~cm} \mathrm{CRL}$ ) were removed from liquid nitrogen and thawed at $37^{\circ} \mathrm{C}$ in a water bath. Gonads were then rinsed in ice-cold PBS, minced into $\sim 0.1 \mathrm{~mm}$ pieces and incubated in Collagenase Type IV (800 U/mL) (LS004186, Worthington) supplemented with DNase I (6 U/mL) (04536282001, Roche Applied Science) at $37^{\circ} \mathrm{C}$ in a prewarmed orbital shaker for $10 \mathrm{~min}$ at 150 rpm. After dissociation, the cell suspension was filtered and dead cells were removed by magnetic bead sorting using a Dead Cell Removal Kit (13009010, Miltenyi) following the manufacturer's protocol. Viable cells resuspended in $0.4 \%$ BSA were submitted on ice to the UC Davis DNA Technologies \& Expression Analysis Core for library preparation and sequencing.

\section{0x Genomics library preparation and sequencing}

Cells were captured using a $10 \times$ Chromium controller targeting 10,000 cells per sample. Libraries were prepared using the Chromium Single Cell 3' v2 chemistry for sample 1 and $\mathrm{v} 3$ chemistry for sample 2 according to the manufacturer's protocol. Sequencing was performed in an Illumina HiSeq 4000 platform as 150 base paired-end.

\section{Mapping, cell quality control and downstream analyses}

Demultiplexing of raw reads and mapping to the bovine reference genome (ARS-UCD1.2.96) was performed using the Cell Ranger software (v3.0.2). Reads were filtered and counted through the Cell Ranger Count pipeline. The R package Seurat (v3.1.0.9003) was used for sample integration, quality control,

Table 2 Sequence of primer sets used for qPCR.

\begin{tabular}{|c|c|c|c|c|}
\hline Gene & Forward primer sequence & Reverse primer sequence & $\operatorname{Tm}\left({ }^{\circ} \mathrm{C}\right)$ & $\begin{array}{l}\text { Amplicon } \\
\text { size (bp) }\end{array}$ \\
\hline$D D \times 4$ & GAAGGTGATAGCTCTGGTTTCT & GTCTTGATAACCGССТСТСTT & 62 & 99 \\
\hline HMBS & СTTCACCATTGGAGCTGTCT & TAGTTCCTACCACACTCTTCTCT & 62 & 116 \\
\hline NANOS3 & TGTGCAGGTTCCAAAGGT & GTCTCСTTAGGCAGAAGTTGAG & 62 & 81 \\
\hline PRDM1 & CCACATGAATGCCAGGTTTG & TGCACTGGTAAGGTTTCTCTC & 62 & 97 \\
\hline PRDM14 & GGACAAGGGTGACAGGAAAT & TCCCGCATGTAGAACACTTG & 62 & 128 \\
\hline POU 5F1 & AACGAGAATCTGCAGGAGATATG & TCTCACTCGGTTCTCGATACT & 62 & 87 \\
\hline SOX2 & CATTAACGGCACACTGCCCC & TGAAAATGTCTCССССGССС & 62 & 76 \\
\hline SOX17 & AAGATGCTGGGCAAGTCG & CGGTACTTGTAGTTGGGATGG & 62 & 116 \\
\hline TFAP2C & CGACATGGCACACCAGAT & GGAAATAGGACCTTTGCGAATAAC & 62 & 94 \\
\hline$D D \times 3$ & AGGAAGCCAGGAAAGTAA & CATCCACGTTCTAAGTCT & 58 & 184 and 208 \\
\hline
\end{tabular}

Tm, melting temperature. 
and secondary analyses (Stuart et al. 2019). Quality check of datasets and cell filtering was based on 4 criteria: number of detected genes, number of unique molecular identifiers, percentage of mitochondrial genes, and percentage of ribosomal genes. Cells that passed the selection criteria (cells containing 200 to 6000 reads and $<5 \%$ of mitochondrial genes) were used for downstream analysis (Supplementary Fig. 1A, see section on supplementary materials given at the end of this article). Integration and normalization of the two replicates was performed by identifying 'anchors' across datasets. Dimensionality reduction was performed by uniform manifold approximation and projection (UMAP) and differential gene expression was performed using nonparametric Wilcoxon rank sum test, which is part of the standard Seurat pipeline. Functional clustering of gene ontology (GO) term enrichment of differentially expressed genes was performed using DAVID (Huang et al. 2009). The integration of bovine and human data sets was performed using the human UMI count data from http://github.com/ zorrodong/germcell ( $\mathrm{Li}$ et al. 2017). Only female cells expressing 2000 to 10,000 genes and 100,000 to $1,100,000$ transcripts were kept for integration, resulting in 970 total cells. Integration of the bovine and human datasets was also performed by the identification of 'anchors' using R package Seurat (v3.1.5.9003) (Stuart et al. 2019) and variations due cell cycle heterogeneity were regressed out. The identification of candidate surface marker genes was performed using the computational framework COMET (Delaney et al. 2019) using their stand-alone software package.

\section{Data availability}

Accession numbers for the $10 \times X$ Genomics single cell RNA-seq data that support the findings of this study are openly available at https://www.ncbi.nlm.nih.gov/geo/, GEO accession: GSE162952. Code availability of the custom scripts used can be found on GitHub at https://github.com/deliasoto/ Bovine_scRNA-seq.

\section{Results}

\section{Morphology and alkaline phosphatase activity of bovine fetal gonads}

We evaluated the anatomical relationship of the developing gonad with the mesonephros between 40 and 50 days of fetal age $(2-4.5 \mathrm{~cm} C R L)$ by $\mathrm{H} \& \mathrm{E}$ staining. At 40 days of fetal age (Supplementary Fig. $2 \mathrm{~A}$ and $\mathrm{B}$ ), the gonads were identified by their ventral location to the mesonephros, one of the biggest organs in the abdominal cavity at this stage. Around 10 days later (Supplementary Fig. 2C and D), gonads had tripled in size and grown out from the mesonephros. Similar to other mammals, bovine PGCs possess temporary AP activity that is lost upon differentiation (Gropp \& Ohno 1966, Lavoir et al. 1994). We detected nonspecific AP activity throughout the fetal gonad in ovaries and testes (Supplementary Fig. 2E, F and G). In ovaries at 50 days of fetal age $(3.5 \mathrm{~cm} \mathrm{CRL})$, AP positive cells were detected throughout the whole organ, but the surface epithelium seemed to be AP negative. In testes, positive cells in the seminiferous tubules progressively lost AP activity between 60 and 80 days of development (6-12 $\mathrm{cm} \mathrm{CRL),} \mathrm{whereas} \mathrm{somatic} \mathrm{cells} \mathrm{in} \mathrm{the} \mathrm{interstitium}$ remained AP positive. Thus, in female and male fetal gonads, germ cells were masked by the positive AP reaction of the surrounding cells, confirming the lack of specificity of AP staining that others have described (Gropp \& Ohno 1966, Lavoir et al. 1994, Wrobel \& Süß 1998). Even though bovine fetal gonads can be easily identified after 40 days of development, AP activity is not an appropriate germ cell marker as it is unspecific and germ cells lose AP expression over time.

\section{Single-cell RNA-sequencing of 50 days old bovine fetal ovaries}

Since specific surface markers and antibodies to sort the different cell populations of the bovine fetal gonad are not available, we performed scRNA-seq on dissociated fetal gonads to capture the molecular signatures of the bovine germline and its niche. A total of 19,499 cells from two independent replicates of approximately 50 days of fetal age ( $4 \mathrm{~cm} \mathrm{CRL}$ ) were sequenced obtaining $564,587,528$ sequence reads, with 64,039 and 22,332 mean reads per cell in sample 1 and 2, respectively (Supplementary Fig. 1A). After filtering out cell doublets and low-quality cells, 15,548 cells were used for clustering. We identified 11 cell clusters with all clusters being represented in each replicate (Supplementary Fig. 1B). Cluster identity was assigned based on the expression of well-conserved marker genes (Fig. 1 A and B) and functional GO term enrichment (Supplementary Table 1). Cells allocated to cluster 5 were identified as PGCs based on the expression of pluripotency and germline-specific genes such as NANOG, OCT4 (also known as POU5F1), NANOS3, and EPCAM (Fig. 1B and C). PGCs represented $10.8 \%$ of the cells present in the fetal gonad. Clusters 0,1 , and 2 expressed genes associated with stromal (NR5A1 and COL1A2) and epithelial (KRT19 and MSLN) cell populations of the fetal ovary (Jameson et al. 2012, Mork et al. 2012, Hummitzsch et al. 2013), and respectively represented $51.7,20.1,17.5 \%$ of the cells restricted to the somatic and germ cell compartment. GO analysis indicated that clusters 0,1 , and 2 showed specific enrichment for terms such as collagen and extracellular matrix, translation and cell-cell adhesion, and cell proliferation, respectively (Supplementary Table 1 ). Thus, we identified clusters 0,1 , and 2 as stromal cells, quiescent epithelial cells and proliferative epithelial cells, respectively (Fig. 1B and C). Clusters 3, 4, 6, 7, 8, 9 , and 10 represented $29.7 \%$ of the total cells analyzed and corresponded to endothelial cells, erythrocytes, 


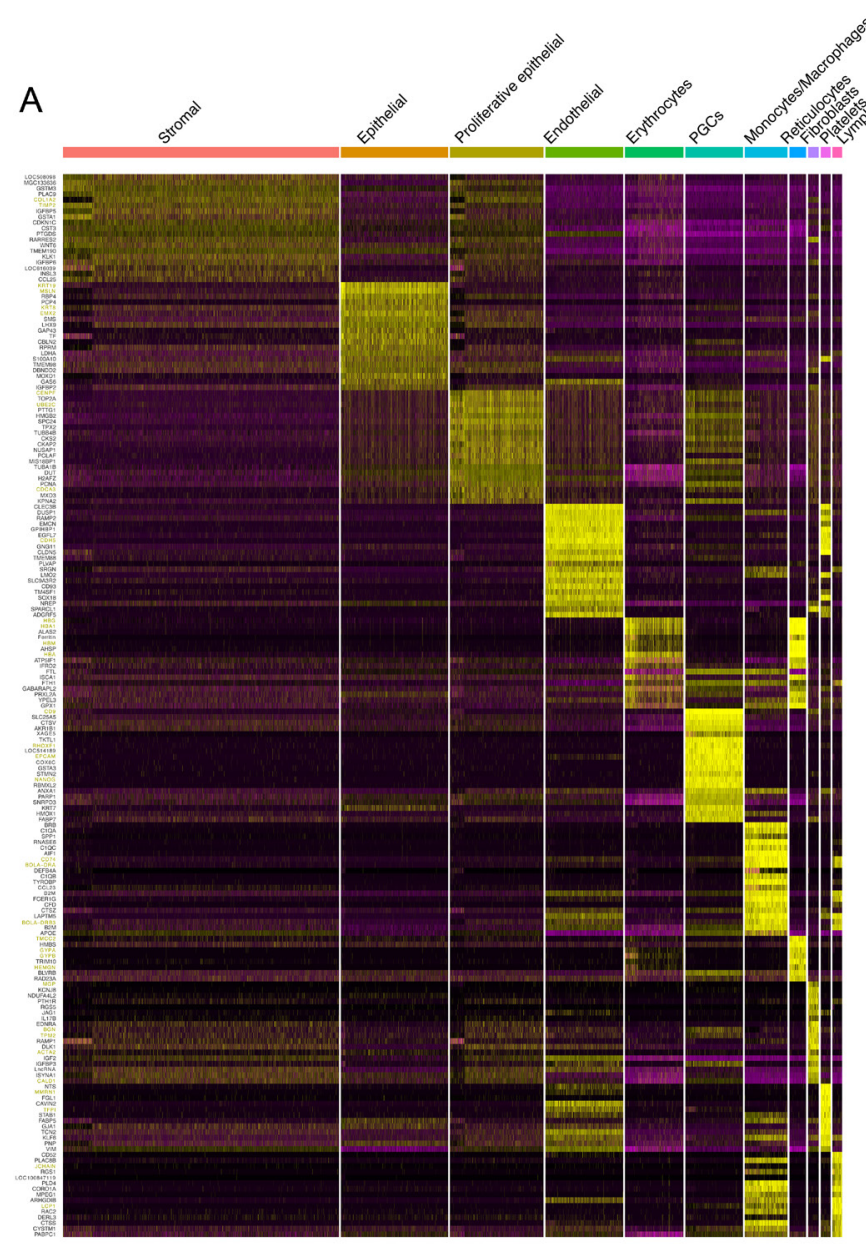

\section{$B$}
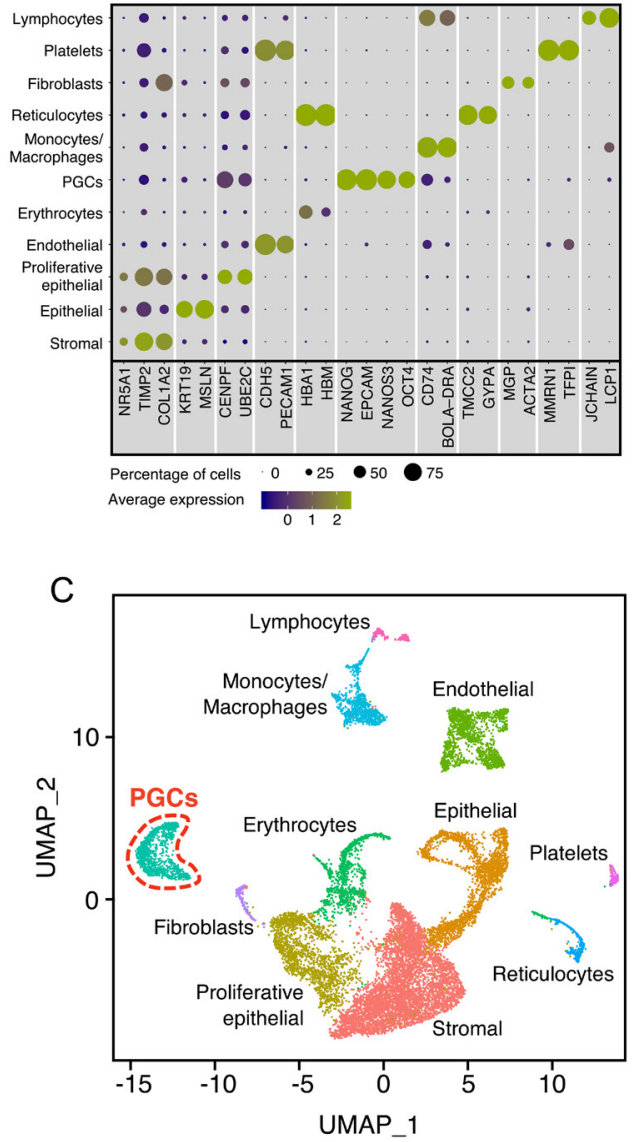

Figure 1 Cell populations detected by scRNA-seq in the bovine fetal ovary at 50 days of fetal age. (A) Heatmap of differentially expressed genes in each cell cluster. Genes used for cluster identification are colored in yellow. (B) Dot plot of the average level of expression (dot color) and percentage of positive cells (dot size) expressing specific marker genes in each cell cluster. (C) Identity of cell populations in UMAP projection.

monocytes/macrophages, reticulocytes, fibroblasts, platelets, and lymphocytes, respectively (Fig. 1C). This analysis demonstrated that different cell populations, including PGCs, can be identified in the bovine fetal gonad by scRNA-seq.

Evaluation of the gene expression profile of the somatic compartment (clusters 0, 1 and 2) (Supplementary Fig. 3) showed high expression of genes involved in the development of the genital ridge (WT1, GATA4, SF1, EMX2 and LHX9) (Luo et al. 1994, Miyamoto et al. 1997, Birk et al. 2000, Hammes et al. 2001, Kusaka et al. 2010, Hu et al. 2013). On the other hand, genes associated with pre-granulosa cells (LGR5, RSP01, WNT4, FOXL2 and FST) (Jorgez et al. 2004, Mork et al. 2012, Rastetter et al. 2014, Zheng et al. 2014) presented only low expression in around $5.5 \%$ of the cells. These results indicate that the somatic cells of 50 days old $(4 \mathrm{~cm} C R L)$ bovine fetal gonads are largely undifferentiated and starting the transition toward supportive cells.

\section{Molecular profiling of the bovine germline during early fetal development}

scRNA-seq data indicated that at 50 days of fetal age (4 $\mathrm{cm}$ CRL) most of the cells in the PGC cluster (98.7\%) expressed at least one marker of pluripotency including OCT4 $(72.5 \%)$, NANOG (95.2\%), and SALL4 (47.2\%), or at least one marker of early PGCs development $(95.5 \%)$ including NANOS3 $(80.2 \%)$, KIT $(69 \%)$, and AP $(57.6 \%)$. A smaller subset of cells (21.1\%) expressed genes that characterize pre-meiotic late-stage PGCs including DAZL (6.3\%), DDX4 (16\%), and STRA8 $(0.5 \%)$ (Fig. $2 \mathrm{~A}$ and Table 3). Marker co-expression analysis showed that $76 \%$ of the cells allocated to the PGC cluster shared expression of pluripotency and early markers, with $21 \%$ also co-expressing late PGCs markers (Fig. 2B), indicating that most PGCs in day 50 fetuses are still in early stages of differentiation, with a subset of cells transitioning toward a more advanced stage.

To confirm the early stage of bovine PGCs at 50 days of fetal age $(4 \mathrm{~cm} \mathrm{CRL})$ and assess the developmental 

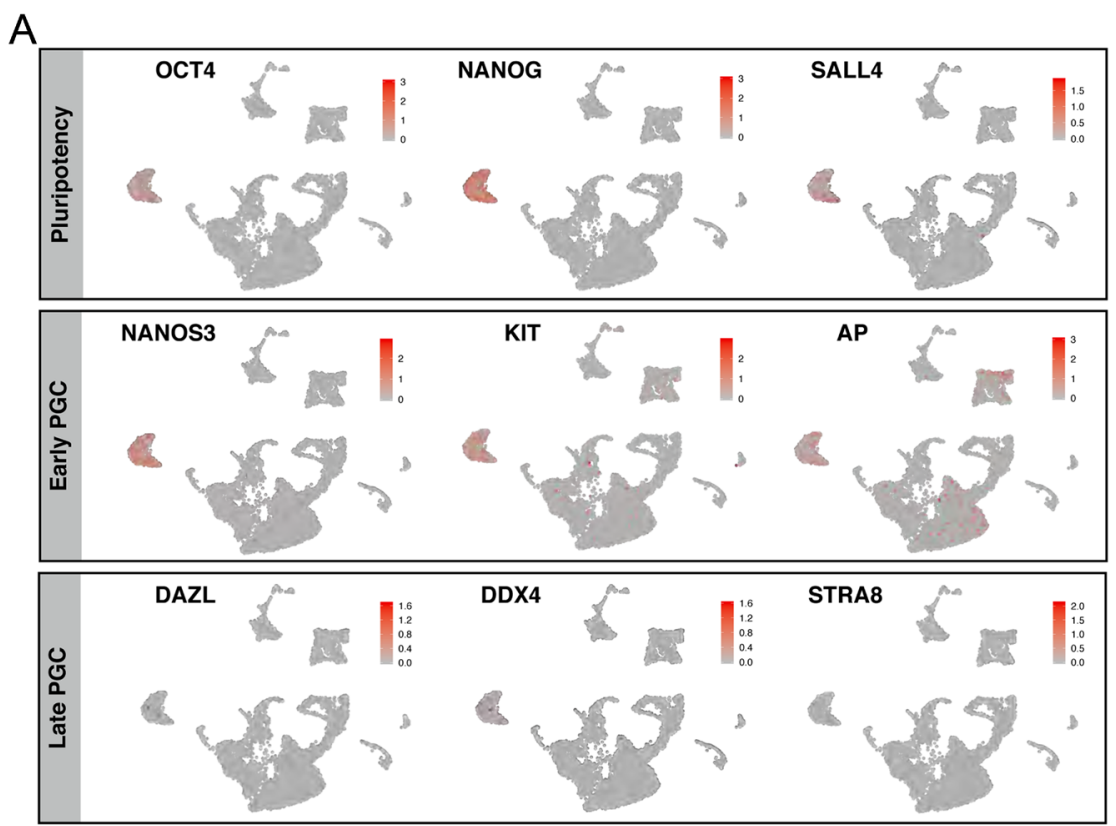

B

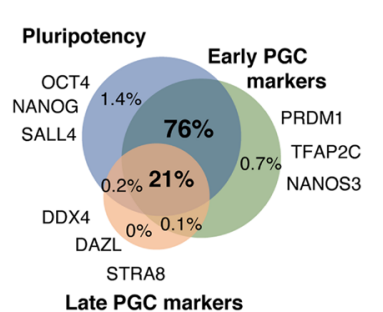

Late PGC markers
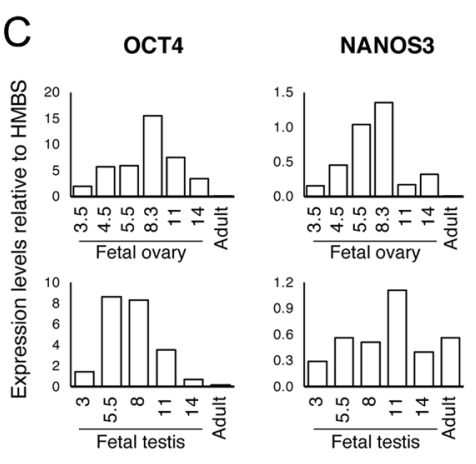

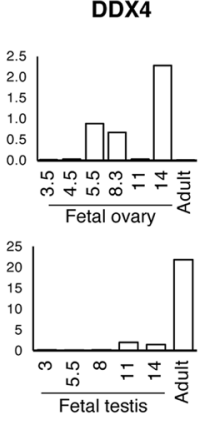

Figure 2 Gene expression profile of bovine PGCs. (A) Level of expression of pluripotency, early and late markers of PGC development in cells of the bovine gonad. (B) Venn diagram of the co-expression of pluripotency, early, and late markers of PGCs development in bovine PGCs. (C) Relative expression of OCT4, NANOS3 and DDX4 in fetal gonads between 45 and 90 days of fetal age and adult testes and ovaries. Numbers in fetal samples represent crown-rump length in $\mathrm{cm}$. timeline of the bovine germline, we analyzed expression of well-known markers of early and late PGC at different stages of development by RT-qPCR and immunofluorescence (Figs $2 \mathrm{C}$ and 3 ). Detection of OCT4, NANOS3, and DDX4 in fetal gonads by RT-qPCR (Fig. 2C) corroborated the findings from scRNA-seq. OCT4 and NANOS3 presented a similar pattern of expression, characterized by a progressive increase during the first 2-3 months of gonad development, likely reflecting PGC proliferation. OCT4 and NANOS3 expression decreased after this period (Fig. 2C). NANOS3 was not detected in adult ovaries, but was expressed in the adult testes, which is consistent with its role during spermatogenesis (Lolicato et al. 2008). Expression of DDX4 increased after 50 days of development $4 \mathrm{~cm}$ CRL) reaching its highest expression in the adult testis (Fig. 2C). Immunofluorescence analyses (Figs 3 and 6) indicated that PRDM1 and OCT4 were equally expressed in female and male PGCs early in development (40-70 days or 2-7 cm CRL). Upon progression of differentiation, PRDM1 and OCT4 were first downregulated in males while in females their expression persisted in germ cells located at the ovarian cortex. DAZL protein was first detected at 60 days $(6 \mathrm{~cm}$ CRL) of development and rapidly became broadly expressed in the germline, especially in males. DAZL detection persisted at 80-90 days (12-16 cm CRL), in spermatogonia and oogonia inside the seminiferous tubules and ovigerous cords, respectively. DDX4 was only detected in the fetal gonads after day 80 of fetal development $(12 \mathrm{~cm} \mathrm{CRL),}$ following DAZL upregulation. Overall, RT-qPCR and immunofluorescence analyses confirmed scRNA-seq results indicating that at day 50 of fetal age $(4 \mathrm{~cm} C R L)$, bovine PGCs are mostly in early stages of development.

\section{Similarities between bovine and human germline development}

Given the early developmental stage of day 50 bovine PGCs, we evaluated the presence of known transcriptional regulators involved in human germline commitment. The signaling cascade that triggers specification of the human germline has been well studied. PRDM1, PRDM14, and TFAP2C form a key 
Table 3 Gene expression profile of female bovine PGCs at 50 days of fetal age.

\begin{tabular}{|c|c|c|}
\hline \multirow[b]{2}{*}{ Genes } & \multicolumn{2}{|c|}{ PGC cluster } \\
\hline & $\begin{array}{c}\text { Number of } \\
\text { positive cells }\end{array}$ & $\begin{array}{l}\text { Percentage of } \\
\text { positive cells }\end{array}$ \\
\hline \multicolumn{3}{|l|}{ Pluripotency } \\
\hline OCT4 & 854 & 72.5 \\
\hline NANOG & 1121 & 95.2 \\
\hline SALL4 & 556 & 47.2 \\
\hline KLF4 & 128 & 10.9 \\
\hline LIN28A & 59 & 5.0 \\
\hline DPPA3 & 0 & 0.0 \\
\hline SOX2 & 0 & 0.0 \\
\hline \multicolumn{3}{|l|}{ Early PGCs } \\
\hline PRDM1 & 794 & 67.4 \\
\hline PRDM14 & 44 & 3.7 \\
\hline TFAP2C & 1006 & 85.4 \\
\hline SOX17 & 1116 & 94.7 \\
\hline SOX15 & 1008 & 85.6 \\
\hline NANOS3 & 945 & 80.2 \\
\hline$A L P L$ & 679 & 57.6 \\
\hline DND1 & 3 & 0.3 \\
\hline \multicolumn{3}{|l|}{ Late PGCs } \\
\hline DDX4 & 188 & 16.0 \\
\hline$D A Z L$ & 74 & 6.3 \\
\hline PIWIL2 & 23 & 2.0 \\
\hline \multicolumn{3}{|l|}{ Meiosis } \\
\hline STRA8 & 6 & 0.5 \\
\hline SYCP1 & 5 & 0.4 \\
\hline SYCP2 & 261 & 22.2 \\
\hline SYCP3 & 479 & 40.7 \\
\hline REC8 & 29 & 2.5 \\
\hline STAG3 & 9 & 0.8 \\
\hline \multicolumn{3}{|l|}{ Oocyte } \\
\hline NOBOX & 1 & 0.1 \\
\hline FIGLA & 1 & 0.1 \\
\hline$Z P 3$ & 57 & 4.8 \\
\hline GDF9 & 4 & 0.3 \\
\hline \multicolumn{3}{|c|}{ Surface proteins } \\
\hline KIT & 813 & 69.0 \\
\hline EPCAM & 1133 & 96.2 \\
\hline PDPN & 1110 & 94.2 \\
\hline ITGA6 & 409 & 34.7 \\
\hline
\end{tabular}

transcriptional network that commands specification of the germline in different species (Ohinata et al. 2005, Yamaji et al. 2008, Kobayashi et al. 2017, Sybirna et al. 2020). Specifically in humans, the SRY-Box proteins SOX17 and SOX15 also play an important role in germline development (Guo et al. 2015, Tang et al. 2015, Kobayashi et al. 2017, Kojima et al. 2017, Chen et al. 2018, 2019). Bovine PGCs expressed PRDM1, TFAP2C, SOX17, and SOX15 transcription factors (Fig. 4A). PRDM14 was only detected in a few cells, which is consistent with observations in human PGCs (Guo et al. 2015, Irie et al. 2015, Tang et al. 2015, Kobayashi et al. 2017) and SOX2, which is only re-activated in mouse PGCs (Western et al. 2005, Perrett et al. 2008, Campolo et al. 2013), was not detected. We confirmed expression of PRDM1, TFAP2C, SOX17, SOX2, and PRDM14 by RT-qPCR in fetal gonads (Fig. 4B). Levels of PRDM1, TFAP2C, and SOX17 increased until days 60-70 of development (approximately $8 \mathrm{~cm} \mathrm{CRL)} \mathrm{and}$ then decreased steadily. Interestingly, PRDM14 shared a similar pattern of expression with PRDM1, TFAP2C, and SOX17, especially in fetal ovaries. Expression of SOX2 was almost undetectable in all the fetal samples evaluated, confirming results of scRNA-seq analysis.

Integration of our dataset with a publicly available single-cell transcriptome of human fetal gonadal cells (FGCs) of 5-26 weeks of development (Li et al. 2017), showed that 50 days old bovine PGCs clustered together with early human germ cells (Mitotic) (Fig. 5A). Bovine PGCs and human mitotic FGCs had a similar gene expression profile, especially for genes involved in germline specification and pluripotency, and genes that characterize early and late PGC development (Fig. 5B). Our scRNA-seq results also revealed that bovine PGCs expressed genes coding for the surface proteins EPCAM (96.2\%), PDPN (94.2\%), KIT (69\%), and ITCA6 (34.7\%) (Table 3), which are also present in human FGCs (Fig. 5C) (Sasaki et al. 2016, Chen et al. 2018). These findings further confirm the similar germline-specific molecular profiles between these two species.

We performed prediction of marker panels by COMET which ranks single or multiple marker genes for identification of cell populations of interest. In line with previous results, EPCAN, KIT and PDPN appeared among the top ranked markers to identify bovine PGCs (Supplementary Fig. 4A and Supplementary Table 3). Interestingly $C D 9$, which has a role during fertilization (Umeda et al. 2020) and is present in $99.7 \%$ of the cells in the PGC cluster and ranked the fifth best marker for PGC identification and isolation. Reliable approaches for the isolation of gonadal somatic cells could be possible using single marker genes (Supplementary Fig. 4B) or by positive and negative selection of marker pairs (Supplementary Fig. 4C).

Exploring the distribution of OCT4 and DAZL in whole ovaries from 40- to 90 day-old fetuses (Fig. 6), we found a progressive loss of OCT4 expression from the center of the ovary outwards to the periphery, while DAZL expression persisted during differentiation, as others have described (Hummitzsch et al. 2013). At 40 days of age, few OCT4-positive cells were detected in the ovary. OCT4-positive cells dramatically increased 20 days later and at day 90 OCT4 was only expressed in cells confined to the vicinity of the surface epithelium. Expression of DAZL was first detected at 60 days of age in cells of the medulla and ovarian cortex. DAZL-positive cells localized in the same pattern of cells expressing OCT4; in fact, all the DAZL-positive cells detected at 60 days co-expressed OCT4. Overall, the expression pattern of germline transcriptional regulators, germlinespecific, pluripotency, and cell surface markers, and the asynchronous pattern of differentiation detected in the bovine germline, revealed important similarities in the development of bovine and human germ cells. 

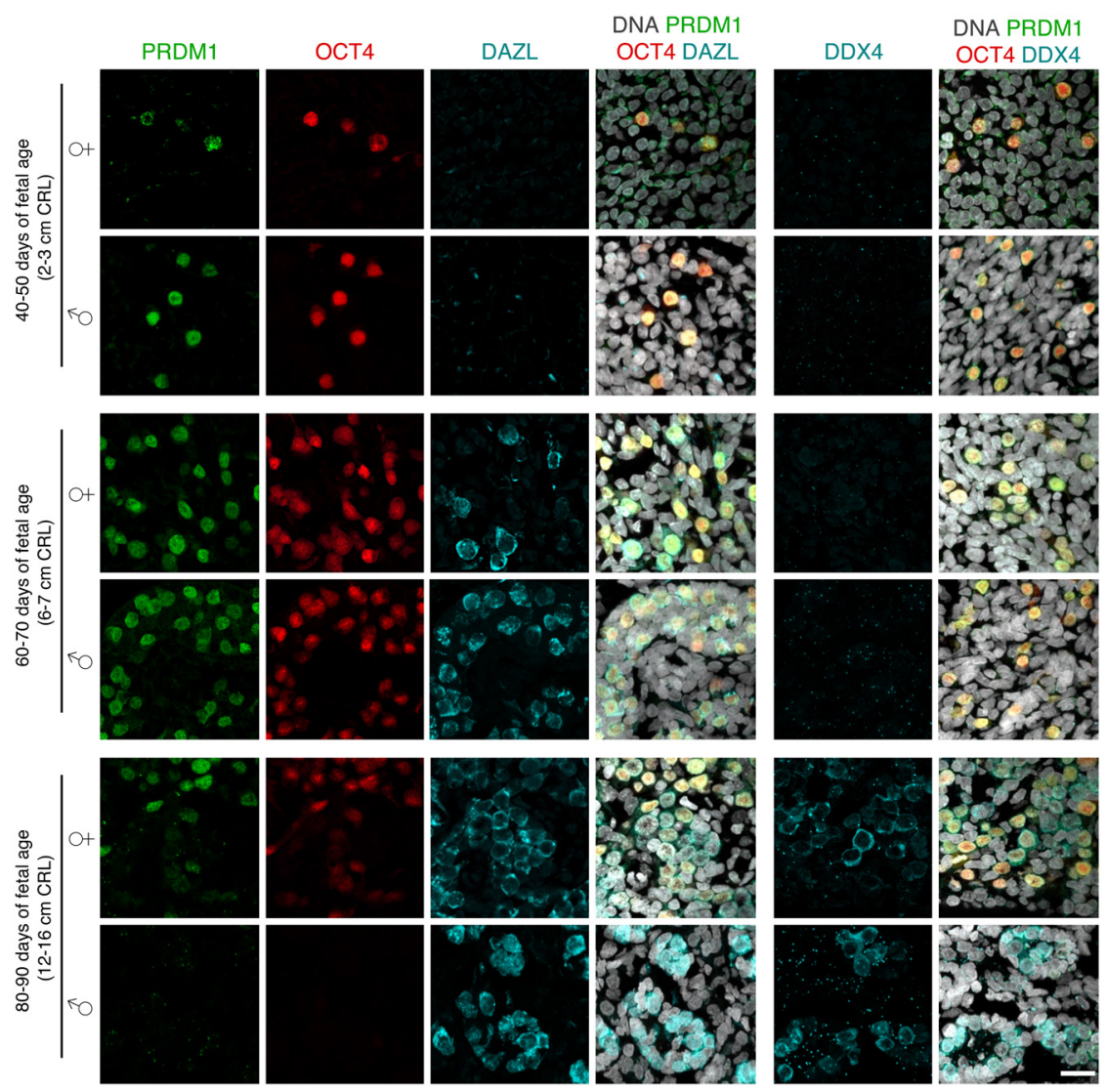

DNA PRDM1 OCT4 DDX4
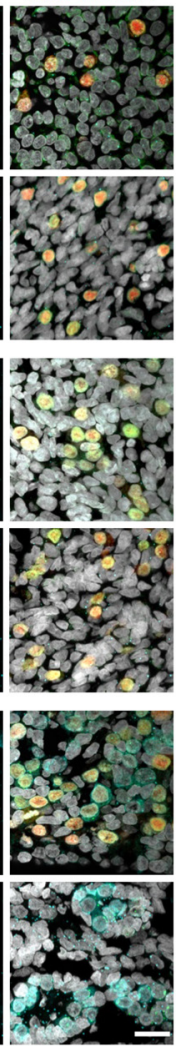

Figure 3 Expression of well-conserved germ cell markers in bovine fetal gonads. Immunofluorescence for PRDM1, OCT4, DAZL, and DDX4 in gonads from 40 to 90 days of fetal age. Nuclear staining was performed using Hoechst 33342. Scale bar 20 $\mu \mathrm{m}$. OCT4 and PRDM1 detection was confined to the nuclei of PGCs, and DAZL and DDX4 to the cytoplasm. This is in agreement with their roles as transcriptional regulators and RNA-binding proteins, respectively.

\section{Expression of mediators of different signaling pathways in the bovine fetal ovary}

Our data confirmed that bovine PGCs express the KIT receptor (Kritzenberger \& Wrobel 2004), while gonadal somatic cells expressed the KIT ligand (KITLG, also known as SCF) (Fig. 7), consistent with previous findings (reviewed by Driancourt et al. 2000).

It has been suggested that bone morphogenetic protein (BMP), Nodal, and Notch signaling cascades have roles in the initial development of the human germline ( $\mathrm{Li}$ et al. 2017). We identified expression of BMP2 and $B M P 4$ ligands in different cell populations, particularly in PGCs (Fig. 7). BMP4 was more broadly expressed than $B M P 2$, and it was among the top differentially expressed genes detected in the PGC cluster (Supplementary Table 2). Receptors (ACVR1, BMPR1A) and effector (SMAD5) of BMP signaling were detected in several cell groups at different levels of expression. Notably, most of the cells expressing ACVR1, BMPR1A or SMAD5 corresponded to stromal cells, epithelial cells, and PGCs.

The Nodal ligand was detected only in a few PGCs, but receptors (ACVR1C, ACVR2A) and nuclear effectors (SMAD2 and SMAD3) of the Nodal cascade, were present in several cell clusters with a higher number of positive cells in the stromal, epithelial, and PGC clusters. Since Nodal and Activin are both members of the TGF $\beta$ superfamily of signaling molecules, and signal through the same mediators (reviewed by Pauklin \& Vallier 2015), we evaluated the expression of the subunits IINHA, INHBA, and INHBB) (Fig. 7) that form Activins $(A, B$, and $A B)$, as well as Inhibins $(A, B$, and $A B)$. We detected expression of the three Inhibin subunits in our dataset, with specific enrichment in stromal cells and epithelial cells.

Members of notch signaling members were found at varying levels of expression in many of the cell populations analyzed (Fig. 7). The Notch ligand DLL3 was mostly detected in PGCs, and the receptors NOTCH2, $\mathrm{NOTCH} 3$, the effector RBPJ (also known as CBF1), which cooperates with Notch intracellular domain to promote transcription, and the target gene HES1, were abundant in stromal and/or epithelial cells. The consistent expression of mediators of KIT, BMP, Nodal/Activin, and Notch signaling in PGCs and supporting somatic cells of the bovine fetal gonad, suggest that these pathways may be involved in the interaction between bovine PGCs and their niche.

\section{Discussion}

Obtaining a pure population of PGCs for molecular profiling is challenging. Previous means used to identify bovine PGCs included AP activity, KIT expression, detection of specific lectins, and histological features. AP activity and KIT expression are unspecific methods 
A

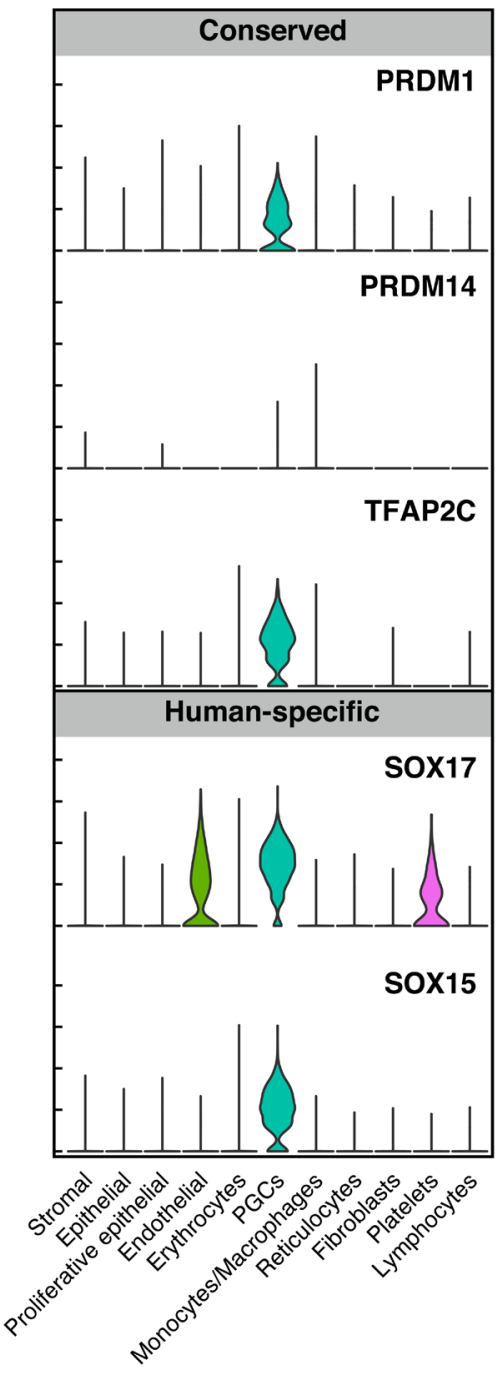

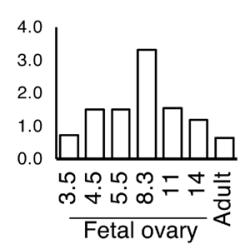
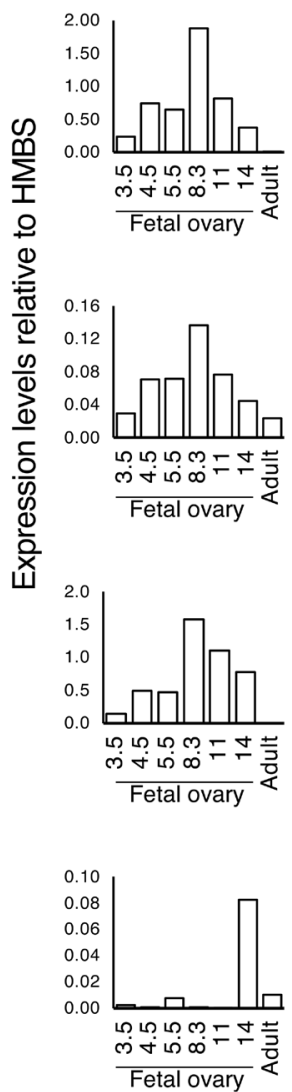

to identify germ cells, as they are also present in hematopoietic cells and gonadal somatic cells (Ohno \& Gropp 1965, Lavoir et al. 1994, Kritzenberger \& Wrobel 2004). Similar to other species, bovine PGCs have a characteristic morphology that allows their identification (Leichthammer et al. 1990, Wrobel \& Süß 1998); however, identification of cells by morphology is impractical, considering the time required for tissue dissociation and manual cell selection. Targeting specific lectins on bovine PGCs does not offer a great advantage either, as glycan-binding antibodies have weak affinity for their target, leading to poor sensitivity (Haab 2012). DDX4 is a germline-specific marker frequently used for sorting human germ cells, but since the expression of a membrane-bound isoform of DDX4 in pre-meiotic germ cells is debatable, the use of commercially available anti-DDX4 antibodies for sorting purposes has shown conflicting outcomes (Woods \& Tilly 2013, Zarate-Garcia et al. 2016, Wagner et al. 2020). Therefore, by performing scRNA-seq, we overcame the limiting step of cell sorting
PRDM1

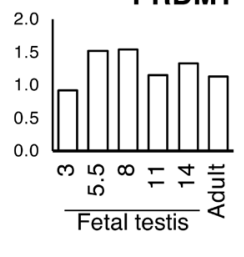

TFAP2C

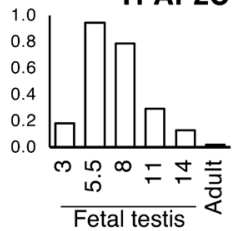

SOX17

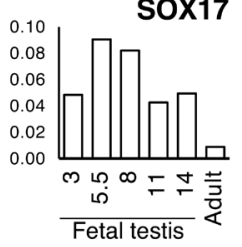

PRDM14
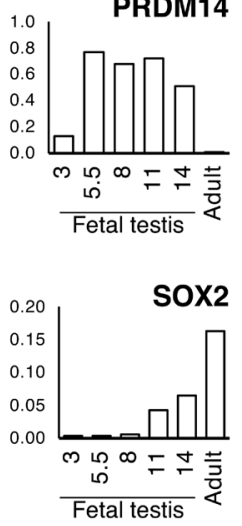

Figure 4 Expression of transcriptional regulators of germline development in bovine PGCs. (A) Violin plots of common (PRDM1, PRDM14 and TFAP2C), and species-specific genes with a function in human (SOX15 and SOX17) germline development. (B) Relative expression of PRDM1, TFAP2C, SOX17, SOX2, and PRDM14 in fetal gonads between 45 and 90 days of fetal age, and adult testes and ovaries. Numbers in fetal samples represent crown-rump length in $\mathrm{cm}$.

and obtained the transcriptional landscape of bovine PGCs and of different cell groups within the fetal ovary.

The relatively undifferentiated state of bovine PGCs captured by scRNA-seq and the positive expression of master regulators of human germline commitment suggest that the signaling network governing bovine PGC specification might be similar to what has been described in humans. Our scRNA-seq data indicated that at 50 days of fetal age, the transcriptional profile of bovine PGCs is characterized by the expression of PRDM1, TFAP2C, SOX17, SOX15, SALL4, LIN28A, KLF4, and ITGA6 (Table 3), with SOX17 being one of the top differentially expressed genes (Supplementary Table 2), and lacking SOX2 expression (Fig. 5B). Therefore, bovine PGCs seem to possess a transcriptional network similar to human PGCs. It has been postulated that SOX17 exerts its critical function in the development of the human germline by regulating gene expression as a binding partner of OCT4 (Tang et al. 2016). Expression of SOX17 and SOX2 are mutually exclusive in human 
A

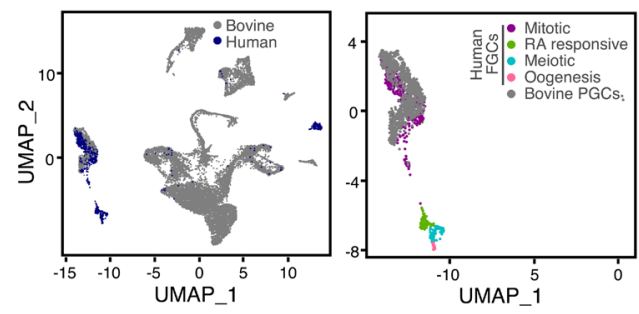

B

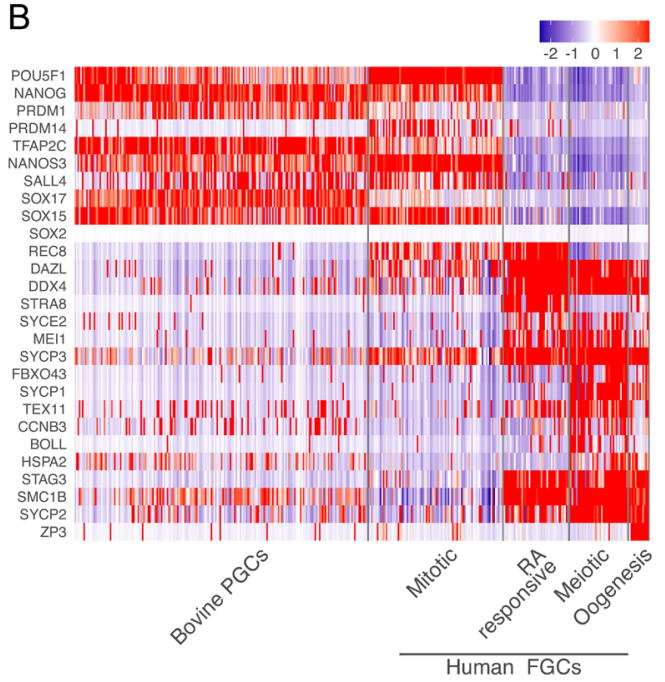

C

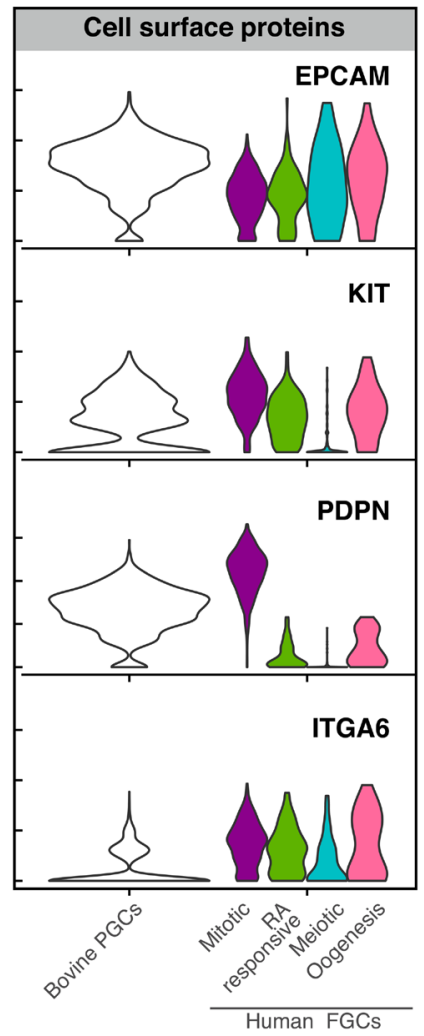

Figure 5 Similarities between bovine and human PGCs transcriptional profile. (A) Integration of scRNA-seq data from bovine (50 days) and human (5-26 weeks) fetal germ cells at different stages of differentiation (Li et al. 2017). (B) Comparison of the expression of germline-specific genes between bovine PGCs and human fetal germ cells (Li et al. 2017). (C) Expression of EPCAM, KIT, PDPN, and ITGA6 genes coding for membrane-bound proteins in bovine PGCs and human fetal germ cells ( $\mathrm{Li}$ et al. 2017). FGCs, fetal germ cells; RA, retinoic acid.
PGCs and downregulation of SOX2 is required for PGC-like cell differentiation in vitro (Lin et al. 2014). OCT4 switches binding partners from SOX2 to SOX17, and regulates the expression of endoderm genes during mouse primitive endoderm differentiation (Aksoy et al. 2013). Interestingly, targets of the SOX17-OCT4 partnership are PRDM1 and SALL4 (Aksoy et al. 2013), which are both also expressed in bovine PGCs (Table 3). Therefore, our data support the notion that there might be a correspondence between embryonic structure and usage of transcription factors, and that SOX17 may be critical in determining PGC fate in species that develop as bilaminar discs, such as pigs, primates and cattle (Kobayashi \& Surani 2018). It will be of interest in the future to evaluate the requirement for SOX17 in the development of the bovine germline.

Unlike PRDM1, which seems to have a conserved role in PGC fate across mammals, PRDM14 function seems to be less explicit. In mouse PGCs, PRDM14 is involved in repressing the somatic program, upregulating germline-specific genes, and promoting epigenetic reprogramming (Saitou et al. 2002, Yabuta et al. 2006, Seki et al. 2007). Instead in human PGCs the role of PRDM14 is less understood. Since in fetal gonads PRDM14 has a cytoplasmic location (Irie et al. 2015) and its knockdown did not affect PGC-like cell specification (Sugawa et al. 2015) it has been suggested that PRDM14 is dispensable for human PGC fate. However, a recent report put in evidence the crucial role of PRDM14 in the differentiation of human PGC-like cells by inducing a rapid and comprehensive loss of endogenous PRDM14 protein (Sybirna et al. 2020). Thus, we compared the expression profile of PRDM14 in bovine and human PGCs and interestingly, only a small group of bovine PGCs expressed PRDM14. This difference could be attributed to a different role of PRDM14 in bovine PGC fate, or possible to the different scRNA-seq platform used between datasets.

The transcriptome of bovine PGCs revealed the expression of genes coding for membrane-bound proteins that could be of utility for cell sorting. Besides the KIT receptor (Kritzenberger \& Wrobel 2004), bovine PGCs also expressed PDPN, EPCAM, and ITGA6. Even though these markers do not seem to be specific to the germline, they may be a good alternative to the also unspecific KIT receptor, especially if they are targeted simultaneously. KIT, AP, PDPN, EPCAM, and ITGA6 have also been used to sort or quantify gonadal and in vitro generated germ cells in humans (Guo et al. 2015, Irie et al. 2015, Sasaki et al. 2015, Kobayashi et al. 2017, Li et al. 2017, Yokobayashi et al. 2017, Chen et al. 2018).

Different signaling pathways have roles in regulating the delicate interaction between PGCs and gonadal somatic cells. BMP signaling has a well-known role in determining germline fate and regulating follicular development (reviewed by Rossi et al. 2016). BMP4 and BMP7, secreted from theca and granulosa cells, are important for the primordial to primary follicle 

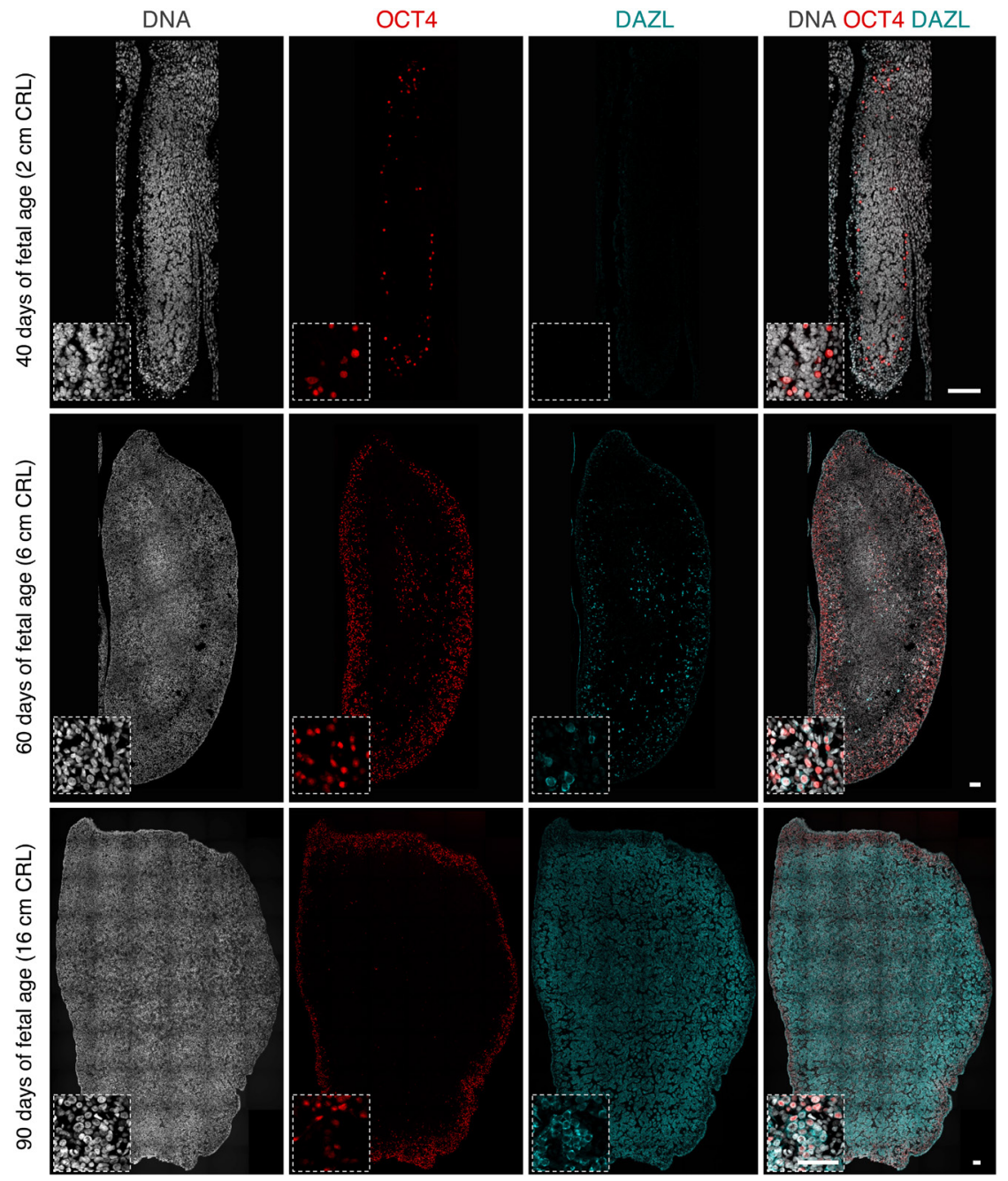

Figure 6 Expression of germ cell markers in whole bovine ovaries. Immunofluorescence for OCT4 and DAZL in the developing ovary. Histological sections were imaged at $20 \times$ and pictures were merged to inspect a complete section of the ovary. Nuclear staining was performed using Hoechst 33342. Scale bars $100 \mu \mathrm{m}$.

transition (Lee et al. 2001, Nilsson \& Skinner 2003). Granulosa cells of human fetal ovaries are characterized by having high expression of BMP2, which possibly plays a role during the mitosis-meiosis transition of germ cells (Li et al. 2017). In the bovine fetal gonad, we detected $B M P 2$ and BMP4 ligands in germ cells, and $B M P 7$ highly expressed in a small group of cells in the somatic compartment. Receptors and mediators of BMP signaling were present in stromal cells, epithelial cells, and PGCs. These results suggest that BMP signaling operates two-ways between PGCs and the somatic compartment in the bovine fetal ovary. Human PGCs might induce differentiation of other germ cells through activation of the Nodal/Activin signaling pathway ( $\mathrm{Li}$ et al. 2017). Our results indicate that Nodal/Activin signaling may also be active in different cell populations of the fetal ovary, but mainly in stromal cells, epithelial cells, and PGCs. We hypothesize that neither Activins nor Nodal ligands are the main drivers of activation of the cascade, but rather, that Inhibins are the ligands that trigger activation of Activin/Nodal pathway in the bovine fetal ovary. Recently the role of the Notch pathway in the development of the mammalian ovary has begun to be elucidated (Vanorny \& Mayo 2017). Notch activation in somatic cells of the mouse fetal ovary is required for germ cell nest breakdown, follicle assembly (Xu \& Gridley 2013, Vanorny et al. 2014), and meiosis entry (Feng et al. 2014). Our scRNA-seq results show high expression of the DLL3 ligand in PGCs, and expression of the NOTCH2 receptor and the target gene HES1 in somatic cells, in agreement with findings in the human fetal gonad (Li et al. 2017). Therefore, these results suggest that Notch signaling plays an important role during gonad development, which is conserved among the mouse, human, and cow.

Another difference between mouse and human germ cells development is the pattern by which differentiation proceeds. In the mouse fetal ovary, meiosis progresses in a rostro-caudal wave (Bowles et al. 2006, Koubova et al. 2006) while in the human fetal ovary meiosis occurs radially (Anderson et al. 2007). Interestingly, our data indicate similarities between the bovine and human germline in terms of spatio-temporal differentiation. In fetal ovaries, we 


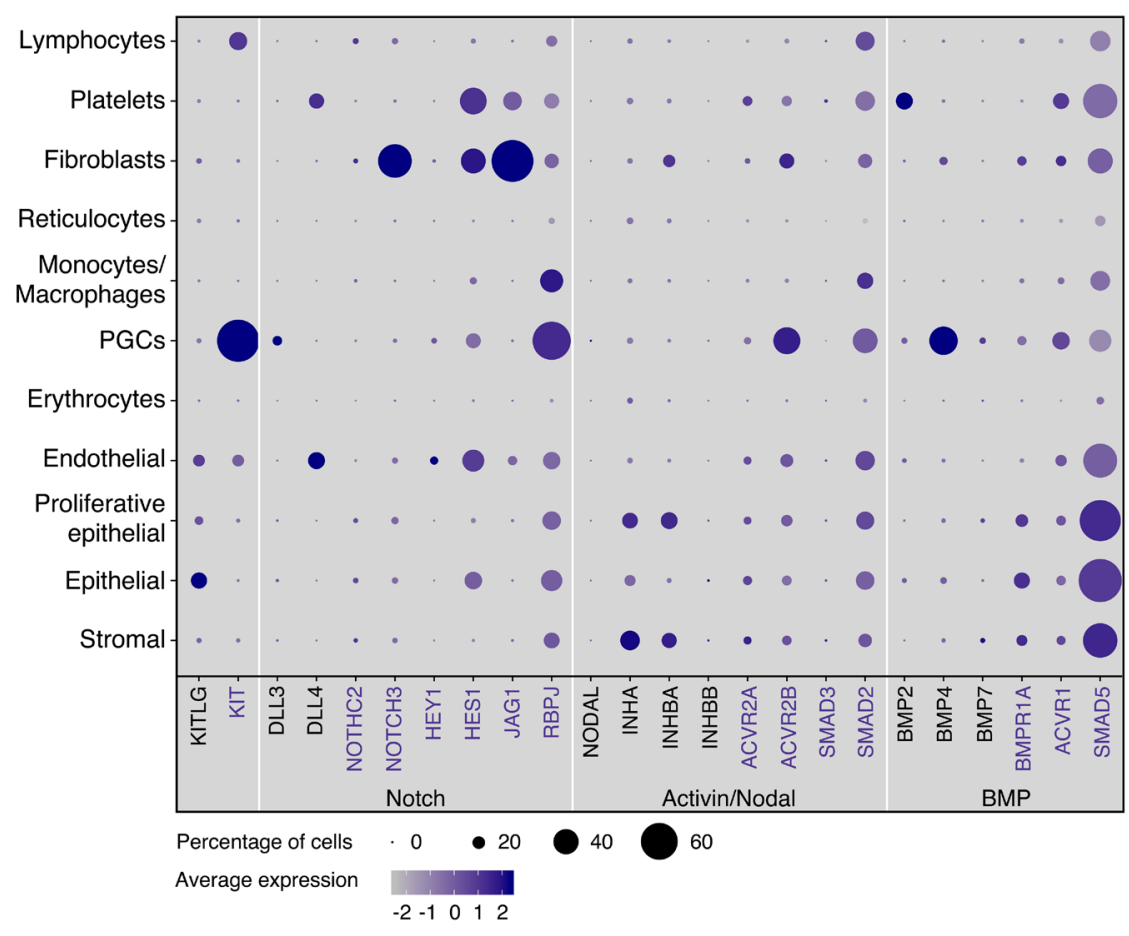

Figure 7 Gene expression of members of different signaling pathways in the bovine fetal ovary. Dot plot of the average level of expression (dot color) and percentage of positive cells in each cell cluster (dot size). Genes in black represent ligands. Genes in purple represent receptors, effectors, or targets of each signaling cascade. detected a progressive downregulation of OCT4 from the center to the periphery. Germ cells in seminiferous tubules also progressively lost expression of OCT4, and only few OCT4-positive cells remained among DAZL/ DDX4-positive cells at day 80 of development. This is in agreement with characterizations of the developing human testis, where differentiation is asynchronous and germ cells expressing early and late markers coexist inside the same seminiferous tubule (Anderson et al. 2007, Sohni et al. 2019). These results may indicate that the progression of bovine PGC differentiation is asynchronous and that germ cells at different stages of differentiation coexist in the fetal gonad, similar to what has been reported for the human ovary (Anderson et al. 2007).

\section{Conclusions}

Results from this work offer new insights into the mechanisms that govern gonadal and germline development in cattle. The data we report here is a useful resource to understand the different cell compartments of the developing gonad, the reciprocal relationship between germ cells and their niche, and the factors that may affect germ cell development. Further, results from this study may provide the basis for developing approaches for in vitro differentiation of bovine gametes from pluripotent stem cells. The similarities we found in the transcriptional profile of human and bovine PGCs confirm that mouse biology can only be partially extrapolated to other mammalian species and indicate that cattle may be a suitable model to study the specification and commitment of PGCs in humans.

\section{Supplementary materials}

This is linked to the online version of the paper at https://doi. org/10.1530/REP-20-0313.

\section{Declaration of interest}

The authors declare that there is no conflict of interest that could be perceived as prejudicing the impartiality of the research reported.

\section{Funding}

This work was supported by UC Davis Chancellor's Fellowship to P J R and USDA program W-4171 and NRSP8. D A S was supported by a doctoral scholarship from CONICYT within the funding program Becas Chile.

\section{Author contribution statement}

D A S was involved in the conception and design, performing experiments, data collection, data analysis, bioinformatics, data interpretation, and manuscript writing. P J R contributed to teh conception and design, financial support, data interpretation, and manuscript writing.

\section{Acknowledgements}

The authors thank the UC Davis DNA Tech Core for support with single cell sample preparation, Prof Anna Denicol for technical recommendations, Carly Guiltinan for proofreading and Ingrid Brust-Mascher for assistance with confocal microscopy. 


\section{References}

Aksoy I, Jauch R, Chen J, Dyla M, Divakar U, Bogu GK, Teo R, Leng Ng CK, Herath W, Lili S et al. 2013 Oct4 switches partnering from Sox2 to Sox17 to reinterpret the enhancer code and specify endoderm. EMBO Journal 32 938-953. (https://doi.org/10.1038/emboj.2013.31)

Anderson RA, Fulton N, Cowan G, Coutts S \& Saunders PTK 2007 Conserved and divergent patterns of expression of DAZL, VASA and OCT4 in the germ cells of the human fetal ovary and testis. BMC Developmental Biology 7 136. (https://doi.org/10.1186/1471213X-7-136)

Bartholomew RA \& Parks JE 2007 Identification, localization, and sequencing of fetal bovine VASA homolog. Animal Reproduction Science 101 241-251. (https://doi.org/10.1016/j.anireprosci.2006.09.017)

Barton LJ, LeBlanc MG \& Lehmann R 2016 Finding their way: themes in germ cell migration. Current Opinion in Cell Biology 42 128-137. (https://doi.org/10.1016/j.ceb.2016.07.007)

Birk OS, Caslano DE, Wassif CA, Cogilatl T, Zhaos L, Zhao Y, Grinberg A, Huang SP, Kreidberg JA, Parker KL et al. 2000 The LIM homeobox gene Lhx9 is essential for mouse gonad formation. Nature 403 909-913. (https://doi.org/10.1038/35002622)

Bowles J, Knight D, Smith C, Wilhelm D, Richman J, Mamiya S, Yashiro K, Chawengsaksophak K, Wilson MJ, Rossant J et al. 2006 Retinoid signaling determines germ cell fate in mice. Science 312 596-600. (https://doi.org/10.1126/science.1125691)

Campolo F, Gori M, Favaro R, Nicolis S, Pellegrini M, Botti F, Rossi P, Jannini EA \& Dolci S 2013 Essential role of Sox2 for the establishment and maintenance of the germ cell line. Stem Cells 31 1408-1421. (https://doi.org/10.1002/stem.1392)

Cantú AV. \& Laird DJ 2017 A pilgrim's progress: seeking meaning in primordial germ cell migration. Stem Cell Research 24 181-187. (https:// doi.org/10.1016/j.scr.2017.07.017)

Cao J, Spielmann M, Qiu X, Huang X, Ibrahim DM, Hill AJ, Zhang F, Mundlos S, Christiansen L, Steemers FJ et al. 2019 The single-cell transcriptional landscape of mammalian organogenesis. Nature $\mathbf{5 6 6}$ 496-502. (https://doi.org/10.1038/s41586-019-0969-x)

Chen D, Liu W, Zimmerman J, Pastor WA, Kim R, Hosohama L, Ho J, Aslanyan M, Gell JJ, Jacobsen SE et al. 2018 The TFAP2C-regulated OCT4 naive enhancer is involved in human germline formation. Cell Reports 25 3591.e5-3602.e5. (https://doi.org/10.1016/j.celrep.2018.12.011)

Chen D, Sun N, Hou L, Kim R, Faith J, Aslanyan M, Tao Y, Zheng Y, Fu J, Liu W et al. 2019 Human primordial germ cells are specified from lineage-primed progenitors. Cell Reports 29 4568.e5-4582.e5. (https:// doi.org/10.1016/j.celrep.2019.11.083)

Delaney C, Schnell A, Cammarata LV, Yao-Smith A, Regev A, Kuchroo VK \& Singer M 2019 Combinatorial prediction of marker panels from single cell transcriptomic data. Molecular Systems Biology 15 e9005. (https:// doi.org/10.15252/msb.20199005)

DesCôteaux L, Gnemmi G \& Colloton J 2009 Practical Atlas of Ruminant and Camelid Reproductive Ultrasonography. Ames, lowa: WileyBlackwell. (https://doi.org/10.1002/9781119265818)

Driancourt MA, Reynaud K, Cortvrindt R \& Smitz J 2000 Roles of KIT and KIT LIGAND in ovarian function. Reviews of Reproduction 5 143-152. (https://doi.org/10.1530/ror.0.0050143)

Erickson BH 1966 Development and radio-response of the prenatal bovine ovary. Reproduction 11 97-105. (https://doi.org/10.1530/jrf.0.0110097)

Feng YM, Liang GJ, Pan B, Qin XS, Zhang XF, Chen CL, Li L, Cheng SF, De Felici M \& Shen W 2014 Notch pathway regulates female germ cell meiosis progression and early oogenesis events in fetal mouse. Cell Cycle 13 782-791. (https://doi.org/10.4161/cc.27708)

Gokulakrishnan P, Kumar RR, Sharma BD, Mendiratta SK \& Sharma D 2012 Sex determination of cattle meat by polymerase chain reaction amplification of the DEAD box protein (DDX3X/DDX3Y) gene. AsianAustralasian Journal of Animal Sciences 25 733-737. (https://doi. org/10.5713/ajas.2012.12003)

Gropp A \& Ohno S 1966 The presence of a common embryonic blastema for ovarian and testicular parenchymal (follicular, interstitial and tubular) cells in cattle, Bos taurus. Zeitschrift für Zellforschung und Mikroskopische Anatomie 74 505-528. (https://doi.org/10.1007/BF00496841)

Guo F, Yan L, Guo H, Li L, Hu B, Zhao Y, Yong J, Hu Y, Wang X, Wei Y et al. 2015 The transcriptome and DNA methylome landscapes of human primordial germ cells. Cell 161 1437-1452. (https://doi.org/10.1016/j. cell.2015.05.015)

Haab BB 2012 Using lectins in biomarker research: addressing the limitations of sensitivity and availability. Proteomics: Clinical Applications 6 346-350. (https://doi.org/10.1002/prca.201200014)

Hammes A, Guo JK, Lutsch G, Leheste JR, Landrock D, Ziegler U, Gubler MC \& Schedl A 2001 Two splice variants of the Wilms' tumor 1 gene have distinct functions during sex determination and nephron formation. Cell 106 319-329. (https://doi.org/10.1016/s00928674(01)00453-6)

Huang da W, Sherman BT \& Lempicki RA 2009 Systematic and integrative analysis of large gene lists using DAVID bioinformatics resources. Nature Protocols 4 44-57. (https://doi.org/10.1038/nprot.2008.211)

Hummitzsch K, Irving-Rodgers HF, Hatzirodos N, Bonner W, Sabatier L, Reinhardt DP, Sado Y, Ninomiya Y, Wilhelm D \& Rodgers RJ 2013 A new model of development of the mammalian ovary and follicles. PLoS ONE 8 e55578. (https://doi.org/10.1371/journal.pone.0055578)

Hu YC, Okumura LM \& Page DC 2013 Gata4 Is Required for Formation of the Genital Ridge in Mice. PLoS Genetics 9 1003629. (https://doi. org/10.1371/journal.pgen.1003629)

Ideta A, Yamashita S, Seki-Soma M, Yamaguchi R, Chiba S, Komaki H, Ito T, Konishi M, Aoyagi Y \& Sendai Y 2016 Generation of exogenous germ cells in the ovaries of sterile NANOS3-null beef cattle. Scientific Reports 6 24983. (https://doi.org/10.1038/srep24983)

Irie N, Weinberger L, Tang WWC, Kobayashi T, Viukov S, Manor YS, Dietmann S, Hanna JH \& Surani MA 2015 SOX17 is a critical specifier of human primordial germ cell fate. Cell 160 253-268. (https://doi. org/10.1016/j.cell.2014.12.013)

Jameson SA, Natarajan A, Cool J, DeFalco T, Maatouk DM, Mork L, Munger SC \& Capel B 2012 Temporal transcriptional profiling of somatic and germ cells reveals biased lineage priming of sexual fate in the fetal mouse gonad. PLoS Genetics 8 e1002575. (https://doi.org/10.1371/ journal.pgen.1002575)

Jorgez CJ, Klysik M, Jamin SP, Behringer RR \& Matzuk MM 2004 Granulosa Cell-Specific Inactivation of Follistatin Causes Female Fertility Defects. Molecular Endocrinology 18 953-967. (https://doi.org/10.1210/ me.2003-0301)

Kobayashi T \& Surani MA 2018 On the origin of the human germline. Development 145 dev150433. (https://doi.org/10.1242/dev.150433)

Kobayashi T, Zhang H, Tang WWC, Irie N, Withey S, Klisch D, Sybirna A, Dietmann S, Contreras DA, Webb R et al. 2017 Principles of early human development and germ cell program from conserved model systems. Nature $\mathbf{5 4 6}$ 416-420. (https://doi.org/10.1038/ nature22812)

Kojima Y, Sasaki K, Yokobayashi S, Sakai Y, Nakamura T, Yabuta Y, Nakaki F, Nagaoka S, Woltjen K, Hotta A et al. 2017 Evolutionarily distinctive transcriptional and signaling programs drive human germ cell lineage specification from pluripotent stem cells. Cell Stem Cell 21 517.e5-532. e5. (https://doi.org/10.1016/j.stem.2017.09.005)

Koubova J, Menke DB, Zhou Q, Cape B, Griswold MD \& Page DC 2006 Retinoic acid regulates sex-specific timing of meiotic initiation in mice. PNAS 103 2474-2479. (https://doi.org/10.1073/pnas.0510813103)

Kritzenberger M \& Wrobel KH 2004 Histochemical in situ identification of bovine embryonic blood cells reveals differences to the adult haematopoietic system and suggests a close relationship between haematopoietic stem cells and primordial germ cells. Histochemistry and Cell Biology 121 273-289. (https://doi.org/10.1007/s00418-0040629-5)

Kusaka M, Katoh-Fukui Y, Ogawa H, Miyabayashi K, Baba T, Shima Y, Sugiyama N, Sugimoto Y, Okuno Y, Kodama R et al. 2010 Abnormal epithelial cell polarity and ectopic Epidermal Growth Factor Receptor (EGFR) expression induced in Emx2 KO Embryonic Gonads. Endocrinology 151 5893-5904. (https://doi.org/10.1210/en.20100915)

Lavoir MC, Basrur PK \& Betteridge KJ 1994 Isolation and identification of germ cells from fetal bovine ovaries. Molecular Reproduction and Development 37 413-424. (https://doi.org/10.1002/mrd.1080370408)

Lawson KA, Dunn NR, Roelen BAJ, Zeinstra LM, Davis AM, Wright CVE, Korving JPWFM \& Hogan BLM 1999 Bmp4 is required for the generation of primordial germ cells in the mouse embryo. Genes and Development 13 424-436. (https://doi.org/10.1101/gad.13.4.424) 
Lee WS, Otsuka F, Moore RK \& Shimasaki S 2001 Effect of bone morphogenetic protein-7 on folliculogenesis and ovulation in the rat1. Biology of Reproduction 65 994-999. (https://doi.org/10.1095/ biolreprod65.4.994)

Leichthammer F, Baunack E \& Brem G 1990 Behavior of living primordial germ cells of livestock in vitro. Theriogenology 33 1221-1230. (https:// doi.org/10.1016/0093-691X(90)90040-Z)

Li L, Dong J, Yan L, Yong J, Liu X, Hu Y, Fan X, Wu X, Guo H, Wang X et al. 2017 Single-cell RNA-seq analysis maps development of human germline cells and gonadal niche interactions. Cell Stem Cell 20858. e4-873.e4. (https://doi.org/10.1016/j.stem.2017.03.007)

Lin IY, Chiu FL, Yeang CH, Chen HF, Chuang CY, Yang SY, Hou PS, Sintupisut N, Ho HN, Kuo HC et al. 2014 Suppression of the SOX2 neural effector gene by PRDM1 promotes human germ cell fate in embryonic stem cells. Stem Cell Reports 2 189-204. (https://doi. org/10.1016/j.stemcr.2013.12.009)

Lolicato F, Marino R, Paronetto MP, Pellegrini M, Dolci S, Geremia R \& Grimaldi P 2008 Potential role of Nanos3 in maintaining the undifferentiated spermatogonia population. Developmental Biology 313 725-738. (https://doi.org/10.1016/j.ydbio.2007.11.011)

Luo X, Ikeda Y \& Parker KL 1994 A cell-specific nuclear receptor is essential for adrenal and gonadal development and sexual differentiation. Cell 77 481-490. (https://doi.org/10.1016/0092-8674(94)90211-9)

Luo H, Zhou Y, Li Y \& Li Q 2013 Splice variants and promoter methylation status of the bovine vasa homology (Bvh) gene may be involved in bull spermatogenesis. BMC Genetics 14 58. (https://doi.org/10.1186/14712156-14-58)

McLaren A \& Southee D 1997 Entry of mouse embryonic germ cells into meiosis. Developmental Biology 187 107-113. (https://doi.org/10.1006/ dbio.1997.8584)

Miyamoto N, Yoshida M, Kuratani S, Matsuo I \& Aizawa S 1997 Defects of urogenital development in mice lacking Emx2. Development 124 1653-1664.

Mork L, MaatoukD, McMahon JA, Guo JJ, Zhang P, McMahon AP, McMahon JA \& Capel B 2012 Temporal differences in granulosa cell specification in the ovary reflect distinct follicle fates. Biology of Reproduction 87 128-128. (https://doi.org/10.1095/biolreprod.111.095208)

Nikolic A, Volarevic V, Armstrong L, Lako M \& Stojkovic M 2016 Primordial germ cells: current knowledge and perspectives. Stem Cells International 2016 1741072. (https://doi.org/10.1155/2016/1741072)

Nilsson EE \& Skinner MK 2003 Bone morphogenetic protein-4 acts as an ovarian follicle survival factor and promotes primordial follicle development. Biology of Reproduction 69 1265-1272. (https://doi. org/10.1095/biolreprod.103.018671)

Ohinata Y, Payer B, O'Carroll D, Ancelin K, Ono Y, Sano M, Barton SC, Obukhanych T, Nussenzweig M, Tarakhovsky A et al. 2005 Blimp1 is a critical determinant of the germ cell lineage in mice. Nature 436 207-213. (https://doi.org/10.1038/nature03813)

Ohno S \& Gropp A 1965 Embryological basis for germ cell chimerism in mammals. Cytogenetics 4 251-261. (https://doi.org/ 10.1159/000129862)

Pauklin S \& Vallier L 2015 Activin/nodal signalling in stem cells. Development 142 607-619. (https://doi.org/10.1242/dev.091769)

Pennetier S, Uzbekova S, Perreau C, Papillier P, Mermillod P \& DalbièsTran R 2004 Spatio-temporal expression of the germ cell marker genes MATER, ZAR1, GDF9, BMP15, andVASA in adult bovine tissues, oocytes, and preimplantation embryos1. Biology of Reproduction 71 1359-1366. (https://doi.org/10.1095/biolreprod.104.030288)

Pepling ME \& Spradling AC 1998 Female mouse germ cells form synchronously dividing cysts. Development 125 3323-3328.

Perrett RM, Turnpenny L, Eckert JJ, O'Shea M, Sonne SB, Cameron IT, Wilson DI, Meyts ER-D \& Hanley NA 2008 The early human germ cell lineage does not express SOX2 during in vivo development or upon in vitro culture1. Biology of Reproduction 78 852-858. (https://doi. org/10.1095/biolreprod.107.066175)

Rastetter RH, Bernard P, Palmer JS, Chassot AA, Chen H, Western PS, Ramsay RG, Chaboissier MC \& Wilhelm D 2014 Marker genes identify three somatic cell types in the fetal mouse ovary. Developmental Biology 394 242-252. (https://doi.org/10.1016/j.ydbio.2014.08.013)

Rossi RODS, Costa JJN, Silva AWB, Saraiva MVA, Van Den Hurk R \& Silva JRV 2016 The bone morphogenetic protein system and the regulation of ovarian follicle development in mammals. Zygote 24 1-17. (https://doi.org/10.1017/S096719941400077X)

Saitou M, Barton SC \& Surani MA 2002 A molecular programme for the specification of germ cell fate in mice. Nature 418 293-300. (https://doi. org/10.1038/nature00927)

Sasaki K, Yokobayashi S, Nakamura T, Okamoto I, Yabuta Y, Kurimoto K, Ohta H, Moritoki Y, Iwatani C, Tsuchiya H et al. 2015 Robust in vitro induction of human germ cell fate from pluripotent stem cells. Cell Stem Cell 17 178-194. (https://doi.org/10.1016/j.stem.2015.06.014)

Sasaki K, Nakamura T, Okamoto I, Yabuta Y, Iwatani C, Tsuchiya H, Seita Y, Nakamura S, Shiraki N, Takakuwa T et al. 2016 The germ cell fate of cynomolgus monkeys is specified in the nascent amnion. Developmental Cell 39 169-185. (https://doi.org/10.1016/j. devcel.2016.09.007)

Seki Y, Yamaji M, Yabuta Y, Sano M, Shigeta M, Matsui Y, Saga Y, Tachibana M, Shinkai Y \& Saitou M 2007 Cellular dynamics associated with the genome-wide epigenetic reprogramming in migrating primordial germ cells in mice. Development 134 2627-2638. (https:// doi.org/10.1242/dev.005611)

Sohni A, Tan K, Song HW, Burow D, de Rooij DG, Laurent L, Hsieh TC, Rabah R, Hammoud SS, Vicini E et al. 2019 The neonatal and adult human testis defined at the single-cell level. Cell Reports 26 1501.e41517.e4. (https://doi.org/10.1016/j.celrep.2019.01.045)

Stuart T, Butler A, Hoffman P, Hafemeister C, Papalexi E, Mauck WM, Hao Y, Stoeckius M, Smibert P \& Satija R 2019 Comprehensive integration of single-cell data. Cell 177 1888.e21-1902.e21. (https://doi. org/10.1016/j.cell.2019.05.031)

Sugawa F, Araúzo Bravo MJ, Yoon J, Kim KP, Aramaki S, Wu G, Stehling M, Psathaki OE, Hübner K \& Schöler HR 2015 Human primordial germ cell commitment in vitro associates with a unique PRDM14 expression profile. EMBO Journal 34 1009-1024. (https://doi.org/10.15252/ embj.201488049)

Sybirna A, Tang WWC, Pierson Smela M, Dietmann S, Gruhn WH, Brosh R \& Surani MA 2020 A critical role of PRDM14 in human primordial germ cell fate revealed by inducible degrons. Nature Communications 11 1282. (https://doi.org/10.1038/s41467-020-15042-0)

Tang WWC, Dietmann S, Irie N, Leitch HG, Floros VI, Bradshaw CR, Hackett JA, Chinnery PF \& Surani MA 2015 A unique gene regulatory network resets the human germline epigenome for development. Cell 161 1453-1467. (https://doi.org/10.1016/j.cell.2015.04.053)

Tang WWC, Kobayashi T, Irie N, Dietmann S \& Surani MA 2016 Specification and epigenetic programming of the human germ line. Nature Reviews: Genetics 17 585-600. (https://doi.org/10.1038/nrg.2016.88)

Umeda R, Satouh Y, Takemoto M, Nakada-Nakura Y, Liu K, Yokoyama T, Shirouzu M, Iwata S, Nomura N, Sato K et al. 2020 Structural insights into tetraspanin CD9 function. Nature Communications 111606. (https://doi.org/10.1038/s41467-020-15459-7)

Vanorny DA \& Mayo KE 2017 The role of Notch signaling in the mammalian ovary. Reproduction 153 R187-R204. (https://doi.org/10.1530/REP-160689)

Vanorny DA, Prasasya RD, Chalpe AJ, Kilen SM \& Mayo KE 2014 Notch signaling regulates ovarian follicle formation and coordinates follicular growth. Molecular Endocrinology 28 499-511. (https://doi.org/10.1210/ me.2013-1288)

Wagner M, Yoshihara M, Douagi I, Damdimopoulos A, Panula S, Petropoulos S, Lu H, Pettersson K, Palm K, Katayama S et al. 2020 Singlecell analysis of human ovarian cortex identifies distinct cell populations but no oogonial stem cells. Nature Communications 11 1147. (https:// doi.org/10.1038/s41467-020-14936-3)

Western P, Maldonado-Saldivia J, van den Bergen J, Hajkova P, Saitou M, Barton S \& Surani MA 2005 Analysis of Esg1 expression in pluripotent cells and the germline reveals similarities with Oct4 and Sox2 and differences between human pluripotent cell lines. Stem Cells 23 1436-1442. (https://doi.org/10.1634/stemcells.2005-0146)

Woods DC \& Tilly JL 2013 Isolation, characterization and propagation of mitotically active germ cells from adult mouse and human ovaries. Nature Protocols 8 966-988. (https://doi.org/10.1038/nprot.2013.047)

Wrobel KH \& Süß F 1998 Identification and temporospatial distribution of bovine primordial germ cells prior to gonadal sexual differentiation. Anatomy and Embryology 197 451-467. (https://doi.org/10.1007/ s004290050156) 
Xu J \& Gridley T 2013 Notch2 is required in somatic cells for breakdown of ovarian germ-cell nests and formation of primordial follicles. BMC Biology 11 13. (https://doi.org/10.1186/1741-7007-11-13)

Yabuta Y, Kurimoto K, Ohinata Y, Seki Y \& Saitou M 2006 Gene expression dynamics during germline specification in mice identified by quantitative single-cell gene expression profiling1. Biology of Reproduction 75 705-716. (https://doi.org/10.1095/biolreprod.106.053686)

Yamaji M, Seki Y, Kurimoto K, Yabuta Y, Yuasa M, Shigeta M, Yamanaka K, Ohinata Y \& Saitou M 2008 Critical function of Prdm14 for the establishment of the germ cell lineage in mice. Nature Genetics 40 1016-1022. (https://doi.org/10.1038/ng.186)

Yokobayashi S, Okita K, Nakagawa M, Nakamura T, Yabuta Y, Yamamoto T \& Saitou M 2017 Clonal variation of human induced pluripotent stem cells for induction into the germ cell fate. Biology of Reproduction 96 1154-1166. (https://doi.org/10.1093/biolre/iox038)

Zarate-Garcia L, Lane SIR, Merriman JA \& Jones KT 2016 FACS-sorted putative oogonial stem cells from the ovary are neither DDX4-positive nor germ cells. Scientific Reports 6 27991. (https://doi.org/10.1038/ srep27991)

Zheng W, Zhang H, Gorre N, Risal S, Shen Y \& Liu K 2014 Two classes of ovarian primordial follicles exhibit distinct developmental dynamics and physiological functions. Human Molecular Genetics 23 920-928. (https://doi.org/10.1093/hmg/ddt486)

Received 5 June 2020

First decision 8 July 2020

Revised manuscript received 11 November 2020

Accepted 1 December 2020 